ROCZNIKI NAUK SPOŁECZNYCH

Tom 12(48), numer $4-2020$

DOI: https://doi.org/10.18290/rns20484-5

\title{
ALLA KYRYDON
}

SERGIY TROYAN

\section{CONCEPTUAL FUNDAMENTALS OF POST-WESTPHALIAN INTERNATIONAL RELATIONS}

\section{INTRODUCTION}

Post-bipolar international relations as a sphere of action and interaction of numerous and various state and non-state actors in political, diplomatic, economic, cultural and humanitarian, scientific and technical, etc. levels are the subject of systematic analysis, which is organically combined with detailed characterization of significant structural and functional components of the whole international complex. Conceptual approaches to understanding the current stage of the evolution of international relations were put in place during the destruction of the bipolar world of the Cold War and the formation of new foundations of the world and international order. The distinctiveness of this process is that the collapse of the postwar system took place in peaceful conditions. Accordingly, there are definitions of a new era in international relations, which have spread rapidly and even become winged. Let's name, for example, S. Huntington's "Clash of Civilizations" or F. Fukuyama's "End of History," E. Toffler's "FutureShock" and "Third Wave," M. Castells' "Information Age," Z. Brzezinski or I. Wallerstein's "World System," A. Strauss's "Unipolar International System" etc.

Alla KYRYDON-Doctor habilit. of Historical Sciences, Professor, Honoured Master of Sciences and Engineering of Ukraine, Director of the State Scientific Institution „Encyclopedic Publishing House"; address for correspondence: 51-a B. Khmelnytsky street, Kyiv, 01030; e-mail: akyrydon@ukr.net; ORCID: https://orcid.org/0000-0003-4375-5350.

SERGIY TROYAN-Doctor habilit. of Historical Sciences, Professor of the University of Rzeszov; address for correspondence: 16C Rejtana, ave., Rzeszov; Professor of the Department of International Relations, Information and Regional Studies of the National Aviation University; address for correspondence: 1 Cosmonavta Komarova, ave., Kyiv, 03058; e-mail: kattis@ukr.net; ORCID: https://orcid.org/0000-0002-3053-6530. 
At the same time, none of the above definitions reflects the complex characteristics of the modern - after 1991 - system of international relations.

Most often, two terms are used to describe the interconnectedness and interdependence of world politics after the fall of the Iron Curtain: the post-bipolar (post-westphalian) international system or international relations after the end of the Cold War. In the first case, the post-bipolar international system seeks to emphasize the disappearance of dualism in the arena of international politics after the collapse of the Soviet Union as a superpower. The United States remains the only superpower, although certain elements of the superpower are inherent in the influential actors of modern international relations. First of all, we are talking about the People's Republic of China, the Russian Federation and the European Union. The well-known American international researcher S. Huntington in his article The Lonely Superpower (1999) ${ }^{1}$ even proposed to regard the international system "after the Cold War" 2 as a combined model in the format of a uni-multipolar world in which US dominance borders on a polycentric conglomerate of the rest of countries. In the second case (the system of international relations after the end of the Cold War), the key to assessing the current state of international relations is the emphasis on the disappearance of the main dividing lines in world politics: between socialism and capitalism, between government control and market economy, and finally between the USSR and the United States. Hence, according to the President of the Council on Foreign Relations, R. Haas, the modern world can be interpreted as "no-polar," where power is distributed among numerous, but "relatively equal" centers. It is not difficult to see that both terms, post-bipolar international system and international relations after the end of the Cold War, have common features, which usually allows them to be used as synonyms and makes them the most popular when choosing a common comprehensive definition for the modern international relations.

\section{STRUCTURAL FEATURES OF MODERN INTERNATIONAL RELATIONS}

It should be noted that the system of international relations in the modern world has a very complex structure and any definition or typology reflects international realities to a greater or lesser extent. One cannot fail to notice the

\footnotetext{
${ }^{1}$ S.P. Huntington, The Lonely Superpower, "Foreign Affairs" 1999, Vol. 78, No. 2, pp. 35-49.

2 R. KuŹNIAR, Pozimnowojenne dwudziestolecie: 1989-2010. Stosunki międzynarodowe na przełomie XX $i$ XXI wieku, Warszawa: Wydawnictwo Naukowe Scholar 2011.
} 
fact that its structure plays a fundamental role in understanding the laws of the functioning of the international system. According to the basic idea, the uncoordinated activities of sovereign states with their interests form an international system, the main feature of which is the dominance of a limited number of the strongest states, and its structure determines the behavior of all international actors. Hence, the most general law of international systems is the dependence of the behavior of actors on the structural characteristics of the system. scientists, such as R. Aron, call the law of equilibrium of international systems or the law of balance of power another most common law, which allows to maintain the relative stability of the international system.

Regarding the transformation of the international system, its basic law is the law of correlation between polarity and stability of the international system. However, the collapse of the Soviet bloc and the global bipolar system put on the agenda issues that cannot be resolved within the traditional terms "poles," "balance of power," "configuration of the balance of power" etc. The world has entered a period of uncertainty and growing risks. According to the definition of the Russian international political scientist A. Bogaturov, "Yalta-Potsdam order collapsed, and the international system began to slide into deregulation." As a result, the global international system is experiencing profound shocks associated with the transformation of its structure, changes in its interaction with the environment, which accordingly affects its regional and peripheral dimensions. Proofs of this are the events around Kosovo, Georgia, Iraq or Afghanistan, and more recently in North Africa and the Middle East, which, according to international relations experts, have entered a period of long-term "emergency."

The Belgian scientist A. Samuel in his book "Nouveau paysage international" even believes that humanity has already entered the "new international world." The American scientist J. Rosenau in his work "Turbulence in World Politics"5 spoke of the "world of post-international politics." First of all, we are talking about the policy of a "bifurcated world," where two simultaneously interdependent and irreconcilable sides were formed. On the one hand, these are traditional interstate relations, which are determined by the "laws" of classical diplomacy and strategy; on the other hand, the interaction of "actors outside sovereignty" i.e. non-state actors in international relations. The relationship

\footnotetext{
${ }^{3}$ А.Д. Богатуров ред. Системная история международных отношений, т. 1. Москва 2006, c. 29.

${ }^{4}$ A. SAmuel, Nouveau paysage international, Lyon: Chronique sociale 1990.

${ }^{5}$ J. Rosenau, Turbulence in World Politics. A Theory of Change and Continuity, New York-London-Toronto-Sidney 1990.
} 
between these two groups of international actors, state and non-state, is very complex and has a structure of a network. This means that any earthquake in one area is immediately reflected in the others, regardless of the boundaries between domestic and international processes, which, although leveled, still persist.

The speed and depth of changes observed in such a "world of post-international politics" has at least three main consequences. First, a transition from a bipolar world to a complex or to some extent transitional postbipolar world had place. "Network" theorists (primarily J. Rosenau and the Anderson's spouses) especially emphasize that everything is so intertwined in the modern world that a return to the previous structure of the world order is impossible. ${ }^{6}$ Secondly, this transitional world has become unpredictable and it is no longer possible to resolve issues of international security only by the old military-force methods with the participation of state participants in the international political process only. Third, information technology is extremely important in today's world, including in world politics. This allowed us to characterize modern society as information one, which has a cardinal influence on the evolution of traditional politics, diplomacy and strategy in international relations. These consequences can be narrowed down to one conclusion: a restructuring of the entire world political space is taking place, which is marked by stochasticity and the influence of new types of phenomena (virtualization, "hybrid war," cyberattacks, assemblage etc.).

Hence, the laws of international relations, although preserved, but acquire new features and are often considered in the form of universal laws or trends in modern international relations. Universal or most general laws must meet the criteria of spatio-temporal and structural-functional nature. This means the following. First, their influence had to impact not only certain regions but the world as a whole. Secondly, they must be observed in historical retrospect, in the current development of international relations, as well as not to be excluded in the future. Third, they must cover all participants in international relations and all spheres of public life. Hence, we can identify two main universal patterns or two leading trends in the development of modern international relations. These include globalization and fragmentation of international relations, the formation of a single, integrated world and all new forms of its polarization. These universal laws are dialectically opposite sides of one internally contradictory

${ }^{6}$ Information technologies and global politics: the changing scope of power and governance, eds. J. Rosenau, J.P. Singh, New York: State University of New York Press 2002; J. RosenAU, Study of World Politics, Vol. I, Theoretical and Methodological Challenges, London-New York: Routledge 2006, pp. 7-10. 
tendency: the growing interdependence of the modern world, as well as its specific, often contradictory and even unpredictable instances in the field of international relations.

\section{POST-WESTPHALIAN INTERNATIONAL RELATIONS: FROM UNIPOLAR TO MULTIPOLAR WORLD}

The end of the Cold War era with the collapse of the USSR and the end of the world system of socialism resulted in the transformation of the United States into a hegemon on the international arena in the 1990s. This was determined by the fall of the Eastern bloc led by the USSR, as well as the powerful economic, financial, trade, information, political, military capabilities of the United States to influence the international situation, its nature and course. According to proponents of the dominance and leading role of the United States in international relations in the 1990s, they have become a "single superpower," a leader, a hegemon, and the center of a new imperial-type international system. ${ }^{7} \mathrm{How}-$ ever, this unipolar world could not last long in time. This, in particular, drew the attention of Western researchers in $1994 .{ }^{8}$ General trends in the development of a multipolar world and gradual reduction performance abilities US effectively influence world development across complexity, inconsistency and global problems of international relations, occurrence/recovery and active development of new centers of power already in the short term, showed the necessity of forming a multipolar world or complex.

The limited capacity of the United States to maintain a unipolar world was largely confirmed by the realities of international relations in the XXI century. The fight against international terrorism against the background of the tragic events of September 11, 2001, steadily dictated the creation of an international anti-terrorist coalition. The United States was unprepared to respond unilaterally to a wave of armed and peaceful protests and social protests in the Arab world. The Arab revolutions, and especially the events of the civil war in Syria and external intervention in it, have also shown the limited ability of the United States to influence the situation. This means that the American strategy of managed crises and conflicts (strategy of managed chaos) has lost its

\footnotetext{
${ }^{7}$ J.S. NyE JR., The Paradox of American Power: Why the World's Only Superpower Can't Go It Alone, Oxford, New York: Oxford University Press 2002; W.C. WOHLforTh, The Stability of a Unipolar World, "International Security" 1999, Vol. 24, No. 1, pp. 5-41.

${ }^{8}$ A.L. Friedberg, The Future of American Power, "Political Science Quarterly," Spring 1994, Vol. 109, No. 1, pp. 20-21.
} 
effectiveness and requires at least a "restart." Russia's violations of international treaties on Georgia and Ukraine, the annexation of the territories of independent UN member states and the threat of destruction of the entire system of modern international law, as well as Russia's growing influence in the anti-American Islamic world are also evidence of limited US capabilities to restore the status quo.

This is associated by the researcher with a number of challenges to the unilateral dominance of the United States. F. Zakaria called this phenomenon "the rise of others," among which - the growth of economic and military power of the European Union; tangible economic and even military opposition from the United States by such Asian giants as China, Japan, and India; the desire to gain real influence on world politics, and in particular within the Western Hemisphere, from Mexico and Brazil; transformation of the Russian Federation into a powerful imperial center, especially in terms of geopolitical and geoeconomic (primarily-energy) influences in the post-Soviet space.

It should be noted that the process of forming multipolarity in international relations, although clearly evident, is still far from complete and is extremely controversial. Thus, showing the tendencies of confrontation with the United States, the EU at the same time remains an element of the only Western civilization with the United States with common values and ideological orientations for them. Europe has not yet identified the position of a new cultural, historical, economic and political center, an alternative to that retained by the United States. Even more problematic from an economic, political, military point of view, the above can be considered in relation to countries such as Russia or China, or even the imaginary alliance of Russia and China, directed against the United States. The own interests of each of the potentially new centers of power in modern international relations-China, the EU, Russia, India, Brazil etc. - very often do not coincide in political, economic, security and other areas. This leads to confrontation between them at both the global and regional levels, and as a result — to the increase of global instability, the resolution of wars or armed conflicts.

There is also a decline in the effectiveness of leading international organizations, including the UN and the OSCE, in the political settlement of existing security problems. To some extent, this statement also applies to NATO as one of the main security instruments in modern international relations. This is evidenced by local military conflicts and wars of low and medium duration and intensity in Afghanistan, Iraq, Georgia, Ukraine, Libya, Syria, Azerbaijan and others.

${ }^{9}$ F. ZAKARIA, The Post-American World and the Rise of the Rest, New York-London: W.W. Norton \& Company 2008. 
Thus, the analysis of the main trends in modern international relations shows that in place of a unipolar world with US hegemony, a multipolar world order is being formed. Along with the United States, new centers of power are emerging within it, including China, the EU, India, Brazil, Russia, and so on. We believe that the process of formation of a multipolar post-Westphalian world order will be complex and contradictory with the long-lasting parallel preservation of the role of the United States as the most powerful international actor.

\section{MODELS OF MODERN INTERNATIONAL RELATIONS}

In fact, we can talk about modern international relations, using the concept of assemblage. "Assemblage" is the basic concept of postmodern philosophy. The term was coined by French thinkers Gilles Deleuze and Felix Guattari in "The Thousand Plateau: Capitalism and Schizophrenia"10 to denote a complex set of objects, connections, and relationships as a synthesis of various elements, signs, discourses, and associations that express a particular idea. Deleuze and Guattari singled out two types of assemblies: concrete (or anthropological, a way of constructing one's self, a way of understanding one's identity) and abstract (a striking example of an abstract assembly is, for example, the war machine, the state machine, and the ideology machine, machine of revolution). In the context of the analysis of approaches to the understanding of modern international relations as an "abstract assembly" we will consider the models of S. Cohen, J. Galtung, S. Pereslegin and others. ${ }^{11}$

Already S. Huntington proposed to regard the international system after the Cold War as a combined model in the format of a "unipolar world." 12 In this system of international relations, US dominance borders on the polycentric conglomerate of other countries. Instead, President of the Council on Foreign Relations Incumbent Richard N. Haass believed that the distribution of power and influence in international relations allows us to interpret the modern world

${ }^{10}$ G. Deleuze, F. Guattari, A Thousand Plateaus: Capitalism and Schizophrenia, London-New York 2003.

${ }^{11}$ W.C. WOHLFORTH, The Stability of a Unipolar World, "International Security" 1999, Vol. 24, No 1, pp. 5-41; N.A. SimoniYA, A.V. TorkunOv, The New World Order: From Bipolarity to Multipolarity, "Policy: Political Research" 2015, No 3, pp. 27-37; N. OnUF, Center-Periphery Relations: What Kind of Rule, and Does It Matter?, “All Azimuth" 2017, Vol. 6, No. 1, pp. 5-16.

${ }^{12}$ S.P. Huntington, The Lonely Superpower, "Foreign Affairs" 1999, Vol. 78, No. 2, pp. 35-49. 
as "non-polar," 13 where power is distributed among numerous but "relatively equal" centers: large influential states and blocs of states, international and regional organizations, local military formations, numerous non-governmental organizations and large corporations. In such a multipolar world, no pole of power can dominate, because under hegemony, the model of the international system becomes unipolar. Such a multipolar world can be built 1) on the principle of cooperation (states jointly develop the rules of the game, monitor their observance and punish violators), 2) on the competitive principle (stability is ensured by the balance of power), 3 ) on the conflict principle (when this balance is violated).

The polycentric and hierarchical model of the geostrategic spheres and geopolitical regions of the American Saul Cohen covers five levels ${ }^{14}$ :

- First level-geostrategic areas-Maritime and Eurasian, identified by G. Mackinder. Plus, S. Cohen singles out three more independent entities: South Asia, Middle East, and Central and Eastern Europe as a "gateway" region;

- Second level-geopolitical areas. The Maritime areas include: AngloAmerica and the Caribbean, Western Europe and the Maghreb, Extra-Continental Asia and Oceania, South America and sub-Saharan Africa; Hartland and East Asia are parts of the Eurasian area.

- Third level-first world states and their "cores"- the United States (Atlantic coast, the Great Lakes region); EU ("Central Axis of Development"); Japan (conurbation of the Pacific industrial belt); Russia (industrial-agrarian triangle of St. Petersburg — Rostov-on-Don—Kuzbass); China (East, North, South, and Northeast coastal areas);

- Fourth level—second world states — dominate within the regions, but, due to limited participation in integration entities and international relations, have no global influence: Algeria, Nigeria, South Africa, Australia, Indonesia, Thailand, Vietnam, the Republic of Korea, Turkey, Iran, Iraq, Egypt, Brazil, Argentina, Venezuela, Mexico, Canada;

- Fifth level—subnational territories - the "Gates" (links of communication), which in the future will play the role of leaders in relations between states, stabilizing the global geopolitical system. The "Gates" are usually located along the boundaries of geostrategic areas: the Baltics, Slovenia, the Far East of Russia, Alaska, Hong Kong, Taiwan, Kashmir, Western Australia, Punjab, Eritrea, the

\footnotetext{
${ }^{13}$ R.N. HAASS, The Age of Nonpolarity. What Will Follo U.S. Dominance, "Foreign Affairs," May/June 2008, Vol. 87, No. 3, pp. 44-56.

${ }^{14}$ S. CoHEN, Geopolitics of the world system, Lanham-Boulder-New York-Oxford: Rowman \& Littlefield 2003; S. CoHEN, Geopolitics: the Geography of International Relations, Lanham-Boulder-New York-London: Rowman \& Littlefield 2015.
} 
Azores, Fr. Madeira, Puerto Rico, Hawaii, Quebec, northern Mexico, Catalonia, Gaza, the West Bank, the Basque Country, Lebanon and more. According to the author, being formed as independent geopolitical units, the "Gates" transformed from zones of conflict to zones of compromise development. TNCs that carry out direct foreign investment, technology transfer, and detailed specialization of production can also be such "Gates."

Scandinavian political scientist Johann Galtung in his "Seven Parallels of Unipolar World" hypothesis identified seven centers that can claim global (regional) hegemony ${ }^{15}$ :

- The United States with hegemony in the Western Hemisphere and the Middle East and a desire to be a hegemon of hegemons;

- The EU, which plays on the confrontation between Russia and Turkey;

- Russia with the CIS and possibly the Orthodox and Slavic countries of Central Europe;

- Turkey with more secular Muslim states;

- India and Hindu states;

- China - the spread of influence as a result of "hidden capitalism";

- Japan, which will lack economic leadership.

Even now, six of the seven centers are "coordinated" by the United States, and in the future J. Galtung predicts possible geopolitical coalitions: in particular, the United States - EU-CE and Russia against China-Japan-Korea-Vietnam. He draws this conclusion from an analysis of the confrontation of four worlds: the First is the West, the Second is the post-socialist countries, the Third is the non-aligned countries, and the Fourth is Southeast and East Asia. The main line of division at this stage is between the First and Fourth Worlds. It is possible that all seven centers will be on the path of struggle for markets and raw materials, as they develop in a capitalist way.

Modern Russian physicist, sociologist, writer and alternative historian Sergei Pereslegin proposed an ethnoectopic (displaced) model of a multipolar world. ${ }^{16}$ The essence is following: ethnocultural plates (states), functioning in

${ }^{15}$ J. Galtung, Die andere Globalisierung. Perspektiven für eine zivilisierte Weltgesellschaft im 21. Jahrhundert, Münster: Agenda-Verlag 1998; J. GALTUNG, A Structural Theory of Imperialism - Ten Years Later, Typescript, https://www.transcend.org/galtung/papers/A\%20Structural\%20Theory\%20 of\%20Imperialism\%20-\%20Ten\%20Years\%20Later.pdf (Date of access: 29.09.2020).

${ }^{16}$ С. ПЕРЕСЛЕГИн, Самоучитель игры на мировой шахматной доске, Москва 2005; Б.А. ИСАЕВ, Геополитические модели государства и мира, Научная сессия ГУАП. Сборник докладов: в 3 частях, Часть III. Гуманитарные науки, Санкт-Петербург 2015, с. 31-37; С. ПЕРЕСЛЕГИН, В 2020-м нам придется выбирать между плохим и очень плохим, https://www. business-gazeta.ru/article/453029 (Date of access: 29.09.2020). 
space, collide or creep on each other (shift), increasing their own and decreasing another's ethnocultural space. Under such conditions, there will undoubtedly be conflicts in the physical or semantic space in the form of trade or cultural wars. Hence, examples of such wars can be resource wars, information wars, hybrid wars, and so on.

Director of the Institute of Political Analysis and International Relations $\mathrm{S}$. Tolstov reasonably noted that a specific feature of the modern international system, if interpreted as a state of "diffusion" of unipolarity, or as the initial phase of transition to a multipolar (polycentric) model, are changes in politics and complication of political motivations in relations between the leading states, as well as a significant increase in the number of states involved in the dialogue on fundamental global issues and the search for potential common solutions. In this sense, polarity is expressed primarily as a set of factors and motivations in the relationship between the "old" and "new" large powers (dynamically developing economies), including former third world countries with significant expected development potential. ${ }^{17}$ Other countries that participate in situational regional combinations of interests and forms of interaction and, depending on their individual characteristics and capabilities, participate in regional balances, communities and coalitions also participate indirectly in these processes.

Hence, if we deepen the understanding of global political trends, not only in terms of history but also in the sociology of international relations, based on the study of state influence on society and the study of mechanisms of influence of social communities and institutions on the state and political order in general, we should make an emphasis on the fundamentally important, in our opinion, features of all trends in the evolution of international relations after the Cold War: their vector of development is not straight, but rather has the form of a zigzag, and evolves in a zigzag pattern. This reflects not only the complexity of their course and, accordingly, analysis, but also the dialectic of deep internal contradictions, often ambiguity and even tactical or strategic ambiguity or uncertainty. Such an assessment of the general process of evolution of the basic tendencies of modern international relations not only does not contradict the latter, but in fact reflects their existing and implicit state.

${ }^{17}$ С.В. Толстов, Міжнародна система початку ХХІ століття, „Зовнішні справи” 2013, № 9, c. 8-11, № 10, c. 8-13. 


\section{CONFLICTOGENIC POTENTIAL OF MODERN INTERNATIONAL RELATIONS}

J. Rosenau notes that the world of "post-international politics" is characterized by chaos and unpredictability, distortion of identity, reorientation of traditional ties of authority and loyalty. ${ }^{18}$ In other words, the growing number of participants brings great uncertainty to the system of international relations. Therefore, ensuring the military security of states continues to be an urgent task. In addition, it is accompanied by challenges related to the growing influence of integration and globalization processes, rates in the field of economic competition, the problems of international terrorism, and so on. The state system will eventually give way to the double process of "globalization" and "localization," which Rosenau called "fragmigration" (from fragmentation and integration). ${ }^{19}$

It is necessary to pay special attention to the fact that in the modern world there is a transformation of current concepts and structures of security of the confrontational type into concepts and structures of security based on cooperation. This aspect characterizes the interaction and interdependence of national and international aspects of security. There is a new understanding and interest of each subject in ensuring national security by strengthening international security. But such an understanding, even in the light of current challenges and threats, is not a panacea for the traditional arbitrariness of powerful state actors in the international arena. One recent example is the Russian Federation's annexation and militaristic policy towards Ukraine. In May 2020, A. Merkel said: "Russia is implementing a strategy of hybrid warfare." 20

At the same time, globalization processes lead to the growth of conflictogenity, as they are backed by enormous interests (economic, political, informational, military etc.), fundamental differences between the potential and capabilities of different countries, cultural and civilizational differences and challenges, and the emergence of new and exacerbation of many old global problems. All of the above is expressed in the preservation of the influence of geopolitical, economic, financial, demographic, environmental factors on international relations. Anderson's spouses from Sweden even created their own "network" model in the field

18 J. Rosenau, Turbulence in World Politics. A Theory of Change and Continuity, New York-London-Toronto-Sidney 1990, p. 71.

${ }^{19}$ Idem, New Dimensions of Security: The Interaction of Globalization and Localizing Dynamics, "Security Dialogue" 1994, Vol. 25, No 3, pp. 215-292.

20 Л. ШевцОвА, Кремль не оставил Европе выбора, заставляя ее выйти из угла и вспомнить о своих генах. Россия потеряла Европу, https://enovosty.com/blogs/full/2509-rossiyapoteryala-evropu (Date of access: 29.09.2020). 
of modern world economy and international economic relations. Based on scientific facts and international practice, they consider the rapid integration of national economies into the global economic system to be the main reason for the transformational shifts. Andersons" "network" model can be called a model of the global economy, built on the theory of social networks. From the point of view of the evolution of the modern system of international relations, it should be noted that the tendency to increase the importance and role of geo-economical factors, which significantly complement and expand the field of classical geopolitics, is becoming more and more clear.

The Global Trends 2020 and Global Trends 2030 Estimate, ${ }^{21}$ prepared by the US National Intelligence Council back in 2004 and 2012, stated that the geo-political space dominated by American power would become more complex and diverse. These signs can lead to significant changes in the positioning of the United States, as the rise of China will tend to the role of "balancer" between China, on the one hand, and Japan and other Asian countries, on the other. It has been argued that global development trends require leadership of the United States, but that the American leadership will need skill and ingenuity to reach a consensus. Fierce disputes over ethics and morals will be accompanied by the hopes of some international actors to maintain the role of the United States as the leading guarantor of international security, as only the United States will have enough forces and military means. However, the architecture of international relations is not adapted to ensure the division of responsibilities in security matters. According to the American expert community, no other structure or regional organization than NATO is capable of taking on such a responsibility, although NATO's role has recently provoked the greatest objections from other actors in international relations, primarily the Russian Federation and its allies.

On the other hand, in modern post-bipolar relations of shaky equilibrium, there is an obvious focus on the transformation of the world international order into a "post-American world" (as defined by the famous American political scientist F. Zakaria). ${ }^{22}$ In his like-named book he drew attention to the critical dynamics of relations between old and new actors at the global level. In this context, the question of how other states will respond to the reduction or

\footnotetext{
${ }^{21}$ Global Trends 2030: Alternative Worlds, a publication of the National Intelligence Council, https://www.dni.gov/files/documents/GlobalTrends_2030.pdf (Date of access: 29.09.2020).

${ }^{22}$ F. ZAKARIA, The Post-American World and the Rise of the Rest, New York-London 2008; Debating the Post-American World. What Lies Ahead?, eds. S. Clark, S. Hoque, London-New York 2012.
} 
possible fundamental revision of the role and influence of the United States in the international arena remains open.

\section{CONCLUSION}

Z. Brzezinski in The Great Eurasian Chessboard tried to give an attractive answer to the question "The last global Superpower: what comes next?" $23 \mathrm{He}$ noticed: "Two aspects should be the goal of US policy—and there is no need for apologetics: strengthening America's dominant position over the life of at least another generation, and better-over a longer period, and creating geopolitical structures that can mitigate the inevitable shocks and tensions of social and political changes and at the same time will evolve in the direction of the geopolitical core of joint responsibility for the peaceful management of world processes. The long phase of cooperation with key Eurasian partners stimulated and managed by America will also help to create the preconditions for increasing the role of existing and increasingly inappropriate obsolete UN structures. Then the new division of responsibilities and privileges will respond to the realities of world power, which are now so strikingly different from those that existed in 1945." Further as the text goes: "Thus, in the coming decades, a functioning structure of global cooperation based on geopolitical realities may emerge, and it will later be able to put on the mantle of the current world »regent«, who is still responsible for stability and peace in the world. Achieving geostrategic success in this matter will be a worthy legacy that America will leave behind as the first, only and last truly global superpower."

This means nothing else than relative instability and further shifts in the restructuring of the entire modern system of international relations under the influence of transformational evolution and changes in the world of "post-international politics." The consequence of this at the present stage of the evolution of international relations after the Cold War was the Cold War II. This term has been used since 2010 to describe the political, economic, military and other confrontation between the European Union and the United States, on the one hand, and the Russian Federation, on the other. According to Academician of the Russian Academy of Sciences Yuri Ryzhov, the fundamental difference of the new Cold War is that it is conducted in the conditions of wars of a new nature, hybrid ones. In August 2015, he noted that the Russian authorities, having started an aggression

${ }^{23}$ Z. BRZEZINSKI, The Grand Chessboard: American Primacy and Its Geostrategic Imperatives, New York 1997. 
against Ukraine, had put Russia in a historical and strategic trap, and the Cold War II was approaching its apogee.

"We invite you to the Cold War II" is the title of a recent article by political scientist Dmitri Trenin, director of the Carnegie Moscow Center, in the prestigious Foreign Policy magazine. ${ }^{24}$ The author was probably the first to describe what political analysts on both sides of the Atlantic think that the system of international relations has changed, and even if Russia reduces its pressure on Ukraine, it will not return to its previous state. D. Trenin believes that the Russian occupation of Crimea marked the beginning of the Cold War II, a new round of global confrontation between Russia and the West. He even declares that the previous 20 years of peace were not the end of an old conflict, but only a temporary truce. Now the season of competition between the West and Russia for influence in Eastern Europe is reopened. The question of the further evolution of the entire system of international relations in the post-bipolar (post-westphalian) world and the tendency of its transformation from a confrontational to a system of cooperation remains open.

We consider the process of gradual transition from a unipolar to a multipolar world to be an important trend in the evolution of modern international relations. The way to change the polarity of the international system is determined by the uneven development and changes in the ratio of the potentials of leading actors. Among the countries or blocs of countries that are often considered by modern analysts as possible new-along with the United States-powerful geopolitical centers - the European Union, China, Russia, potentially-even India, Brazil and others. At the same time, the general trends in the evolution of the international system depend primarily on the tactics of the Euro-Atlantic community in terms of the ability to find forms of response and means of influence that can restore control of international political processes and avoid further destructive consequences.

It should also be borne in mind that in the current system of post-Westphalian international relations, associated with the growth of global and regional centers of power, other factors of global importance are also significantly intensified. In this sense, we pay attention to the uncontrolled proliferation of nuclear and missile; international terrorism; maritime piracy; organized and transnational crime; arms and drug smuggling; human trafficking and illegal migration. These factors will not only have an impact on the destabilization of the world order, but also require joint effective countermeasures by real and potential

${ }^{24}$ D. TREnIN, Welcome to Cold War II, https://foreignpolicy.com/2014/03/04/welcome-tocold -war-ii/ (Date of access: 29.09.2020). 
centers of power-states / blocs (US, EU, China, Russia, etc.) and international organizations (UN, OSCE, NATO) - in modern international relations.

\section{BIBLIOGRAPHY}

BrzezInski Z., The Grand Chessboard: American Primacy and Its Geostrategic Imperatives, New York 1997.

CoHen S., Geopolitics of the world system, Lanham-Boulder-New York-Oxford: Rowman \& Littlefield 2003.

COHEN S., Geopolitics: the Geography of International Relations, Lanham-Boulder-New York-London: Rowman \& Littlefield 2015.

Системная история международных отношений, ред. А.Д. Богатуров, т. 1. Москва 2006.

Debating the Post-American World. What Lies Ahead?, eds. S. Clark, S. Hoque, London-New York 2012.

Deleuze G., Guattari F., A Thousand Plateaus: Capitalism and Schizophrenia, London-New York 2003.

Friedberg A.L., The Future of American Power, "Political Science Quarterly," Spring 1994, Vol. 109, No. 1.

Galtung J., Die andere Globalisierung. Perspektiven für eine zivilisierte Weltgesellschaft im 21. Jahrhundert, Münster: Agenda-Verlag 1998.

Galtung J., A Structural Theory of Imperialism - Ten Years Later, Typescript, https://www.transcend.org/galtung/papers/A\%20Structural\%20Theory\%20of\%20Imperialism \%20-\%20Ten\%20Years\%20Later.pdf (Date of access: 29.09.2020).

Global Trends 2030: Alternative Worlds, a publication of the National Intelligence Council, https://www.dni.gov/files/documents/GlobalTrends_2030.pdf (Date of access: 29.09.2020).

HaAss R.N., The Age of Nonpolarity. What Will Follo U.S. Dominance, "Foreign Affairs," May/June 2008, Vol. 87, No. 3.

Huntington S.P., The Lonely Superpower, "Foreign Affairs" 1999, Vol. 78, No. 2.

Information technologies and global politics: the changing scope of power and governance, eds. J. Rosenau, J.P. Singh, New York: State University of New York Press 2002.

KuŹNIAR R., Pozimowojenne dwudziestolecie: 1989-2010. Stosunki międzynarodowe na przetomie XX i XXI wieku, Warszawa: Wydawnictwo Naukowe Scholar 2011.

Nye J.S. JR., The Paradox of American Power: Why the World's Only Superpower Can't Go It Alone, New York: Oxford University Press 2002.

Onuf N., Center-Periphery Relations: What Kind of Rule, and Does It Matter?, "All Azimuth" 2017, Vol. 6, No. 1.

Rosenau J., Turbulence in World Politics. A Theory of Change and Continuity, New York-London-Toronto-Sidney 1990.

Rosenau J., New Dimensions of Security: The Interaction of Globalization and Localizing Dynamics, "Security Dialogue" 1994, Vol. 25, N 3.

Rosenau J., Study of World Politics, Vol. I, Theoretical and Methodological Challenges, London-New York: Routledge 2006.

SAmuel A., Nouveau paysage international, Lyon: Chronique sociale 1990. 
SimoniYa N.A., ToRKunOv A.V., The New World Order: From Bipolarity to Multipolarity, "Policy: Political Research" 2015, No. 3.

TrenIN D., Welcome to Cold War II, https://foreignpolicy.com/2014/03/04/welcome-to-cold-war-ii/ (Date of access: 29.09.2020).

WoHLFORTH W.C., The Stability of a Unipolar World, "International Security" 1999, Vol. 24, No. 1.

ZAKaria F., The Post-American World and the Rise of the Rest, New York-London: W.W. Norton \& Company 2008.

ИСАЕВ Б.А., Геополитические модели государства и мира, Научная сессия ГУАП. Сборник докладов: в 3 частях, Часть III. Гуманитарные науки, Санкт-Петербург 2015 [ISAYEV B.A., Geopoliticheskiyemodeli gosudarstva i mira, Nauchnaya sessiya GUAP. Sbornik dokladov: v 3 chastyakh, Chast' III. Gumanitarnyye nauki,Sankt-Peterburg 2015].

ПеРеСЛеГИн С., Самоучитель игры на мировой шахматной доске, Москва 2005 [PERESLEGIN S., Samouchitel' igry na mirovoy shakhmatnoy doske, Moskva 2005].

ПЕРЕСЛЕГИН С., В 2020-м нам придется выбирать между плохим и очень плохим, [Pereslegin S., V 2020-m nam pridetsya vybirat' mezhdu plokhim i ochen' plokhim] https://www.business-gazeta.ru/article/453029 (Date of access: 29.09.2020).

Толстов С., Міжнародна система початку XXI століття, „Зовнішні справи” 2013, № 9-10 [TOLSTOV S., Mizhnarodnasistema pochatku XXI stolittya, „Zovnishni spravi” 2013, No. 9-10].

ШевцовА Л., Кремль не оставил Европе выбора, заставляя ее выйти из угла и вспомнить о своих генах. Россия потеряла Европу, [SHEvTSOVA L., Kreml'ne ostavil Yevrope vybora, zastavlyaya yeye vyyti iz ugla $i$ vspomnit' o svoikh genakh. Rossiya poteryala Yevropu] https://enovosty. com/blogs/full/2509-rossiya-poteryala-evropu (Date of access: 29.09.2020).

\section{CONCEPTUAL FUNDAMENTALS OF POST-WESTPHALIAN INTERNATIONAL RELATIONS}

\section{Summary}

Conceptual approaches to understanding the current stage of the evolution of international relations were put in place during the destruction of the bipolar world of the Cold War and the formation of new foundations of the world and international order. The distinctiveness of this process is that the collapse of the postwar system took place in peaceful conditions. Most often, two terms are used to describe the interconnectedness and interdependence of world politics after the fall of the Iron Curtain: the post-bipolar (post-westphalian) international system or international relations after the end of the Cold War. Two terms, post-bipolar international system and international relations after the end of the Cold War, have common features, which usually allows them to be used as synonyms and makes them the most popular when choosing a common comprehensive definition for the modern international relations. The collapse of the Soviet bloc and the global bipolar system put on the agenda issues that cannot be resolved within the traditional terms "poles," "balance of power," "configuration of the balance of power" etc. The world has entered a period of uncertainty and growing risks. the global international system is experiencing profound shocks associated with the transformation of its structure, changes in its interaction with the environment, which accordingly affects its regional and peripheral dimensions. In modern post-bipolar relations of shaky equilibrium, there is an obvious focus on the transformation of the world international order into a "post-American world" with the critical dynamics of relations between 
old and new actors at the global level. The question of the further evolution of the entire system of international relations in the post-bipolar world and the tendency of its transformation from a confrontational to a system of cooperation remains open.

Keywords: post-westphalian international relations; world after the end of the Cold War; globalization; integration; turbulence international relations.

\section{KONCEPTUALNE PODSTAWY POSTWESTFALSKICH STOSUNKÓW MIĘDZYNARODOWYCH}

\section{Streszczenie}

Konceptualne podejście do zrozumienia obecnego etapu ewolucji stosunków międzynarodowych pojawiło się podczas upadku dwubiegunowego świata zimnej wojny i tworzenia nowych podstaw porządku międzynarodowego. Specyfika tego procesu polega na tym, że upadek systemu powojennego odbył się w warunkach pokojowych. Najczęściej do opisania powiązań i współzależności polityki światowej po upadku żelaznej kurtyny używa się dwóch terminów - postdwubiegunowy (postwestfalski) system międzynarodowy lub stosunki międzynarodowe po zakończeniu zimnej wojny. Oba terminy, postbipolarny system międzynarodowy i stosunki międzynarodowe po zakończeniu zimnej wojny, mają cechy wspólne, co zwykle pozwala na używanie ich jako synonimów i sprawia, że są one najbardziej popularne przy wyborze wspólnej, kompleksowej definicji współczesnych stosunków międzynarodowych. Upadek bloku sowieckiego i globalny system dwubiegunowy postawiły na porządku dziennym kwestie, których nie da się rozwiązać w ramach tradycyjnych terminów: „bieguny”, ,równowaga sił”, „konfiguracja równowagi sił” itp. Globalny system międzynarodowy przeżywa głębokie wstrząsy związane z transformacją jego struktury, zmianami w jego interakcji z otoczeniem, co odpowiednio wpływa na jego wymiary - regionalny i peryferyjny. We współczesnych postdwubiegunowych relacjach chwiejnej równowagi istnieje oczywisty nacisk na transformację światowego porządku międzynarodowego w „świat postamerykański”, z krytyczną dynamiką relacji między starymi i nowymi aktorami na poziomie globalnym. Otwarta pozostaje kwestia dalszej ewolucji całego systemu stosunków międzynarodowych w świecie postdwubiegunowym i tendencji do jego transformacji z konfrontacyjnego w system współpracy.

Słowa kluczowe: postwestfalskie stosunki międzynarodowe; świat po zakończeniu zimnej wojny; globalizacja; integracja; zawirowania w stosunkach międzynarodowych. 